\title{
A critique of the Swazi Constitutional rules on succession to kingship
}

\author{
Hoolo 'Nyane \\ LLB LLM LLD \\ Associate Professor, School of Law, University of Limpopo
}

\begin{abstract}
SUMMARY
Several aspects of Swazi constitutional law oftentimes present a jigsaw puzzle to many scholars of constitutional law. The promulgation of the new Constitution in 2005 purportedly marked an end to absolutism and ushered in liberal constitutionalism. However, it would seem that the strong role given to customary law in the constitutional design of Swaziland has provided an avenue for absolutism of the monarch. One area of customary law which is still very controversial is the succession to office of King. The Constitution is not elaborate on the rules of succession; it cagily provides that succession to office of King shall be regulated by "Swazi law and custom". In practice, this has effectively given "Swazi law and Custom' pre-eminence over the Constitution. The purpose of this article is to critique the rules of succession to the office of monarch in Eswatini. The paper contends that the Constitution can regain its supremacy by incorporating the customary rules of succession into the Constitution. When those roles have been codified in the Constitution, they can easily be synchronised with other devices of constitutionalism such as human rights and supremacy of the Constitution.
\end{abstract}

\section{Introduction}

The Constitution of Swaziland, ${ }^{1}$ since independence from Britain in 1968, has been consistent in its deference to "Swazi law and custom" in general, and on matters relating to succession to office of King in particular. There is a legion of authorities to the effect that Swazi tradition became much more powerful in Constitutional and political discourse

1 It is important to note that the country's name "The Kingdom of Swaziland" has been changed since April 2018 to the "Kingdom of Eswatini". This change has been effected by the King in accordance with Legal Notice No. 80 of 2018. In terms of the Gazette, the King proclaimed that "[i]n exercise of the powers conferred on me by section 64(3) of the Constitution of Swaziland Act 1 of 2005, I, Mswati III, King and Ingwenyama of Eswatini makes the declaration that the name of the Kingdom of Swaziland is changed to Kingdom of Eswatini." The gazette further provides wherever in any written law or international agreement or legal document to Swaziland shall be read and construed as reference to Eswatini. The Constitutionality of the gazette is a matter of considerable controversy; but for purposes of this paper, the 'The Kingdom of Eswatini' will be used and the word "swazi" will be used as a descriptive word for anything (people, laws, traditions) related to the Kingdom. However, where context demands reference to 'Swaziland', the name will continue to be used.

How to cite: Nyane 'A critique of the Swazi Constitutional rules on succession to kingship' 2019 De Jure Law Journal 65-84

http://dx.doi.org/10.17159/2225-7160/2019/v52a4 
than most countries in Southern African sub-region. ${ }^{2}$ The ascendancy of tradition and custom was obviously bolstered by the collapse of the independence Constitutional edifice in 1973. ${ }^{3}$ Thus, customary law which is the basis for rules of succession to office of king - is unusually strong in Eswtini than in most countries.

Although African indigenous systems sometimes may "reveal sufficient similarity of procedure, principles, institutions and techniques", 4 Swazi customary law has certain features that distinguish it materially from other systems. Most African customary systems are largely unwritten. But the general trend during colonialism has been towards codification of some sort - either through official reports, persuasive codes or actual legislation. ${ }^{5}$ The Swazi indigenous system has resisted all these and remains largely unrecorded. It is a startling outcome of the age-old tradition that has been transferred orally from one generation to the other. However, as Marwick rightly observes, "the repository of these traditions is chiefly the old men, particularly those associated with the King's village where they are continually in attendance listening to and taking part in cases and making use of the code which is to them a living body of precepts". 6

This observation by Marwick makes another striking revelation about the Swazi law and custom - that it is largely the preserve of the royal dynasty. Even today, customary law remains largely known by senior princes in the royal family. This certainly negates the established principle that customary law is the natural outcome of the generally accepted usage by the general body of the people expected to obey such law. Another speculation has been that customary law in Eswatini, by virtue of it being mainly unwritten and being mainly in the hands of the ruling dynasty, has been disturbingly vulnerable to abuse. ${ }^{7}$

2 In general, see Kuper An African Aristocracy: Rank and the Swazi (1947).

Also see Macmillan "Swaziland: decolonisation and the triumph of tradition" 1985 Journal of Modern Africa Studies 643. The author traces the ascendancy of Swazi tradition in an attempt to explain the post-independence state in Swaziland. For the analysis of the tumultuous period between 1973 and 1988, see Maqonqo Kingship and Transition in Swaziland 1973-1988 (MA dissertation 2009 UNISA).

3 See Proclamation by His Majesty King Sobhuza II of 12 th April 1973.

4 Whelpton "Swazi law and custom in the Kingdom of Swaziland" (1997) 20/ 3 South African Journal of Ethnology 145 at 146; see also Allott "The people as lawmakers: custom, practice and public opinion as sources of law in Africa and in England" 1977 Journal of African Law 1.

5 See Allott "What is to be done with African customary law?" 1984 Journal of African Law 56; See also Shadle "Changing traditions to meet the current altering conditions: customary law, African courts and the rejection of codification in Kenya" 1999 The Journal of African History 411.

6 Marwick The Swazi: An Anthropological Account of the Natives of the Swaziland Protectorate (1966) 280.

7 This indictment originates mainly from the anti-monarchist informants who mainly come from the progressive organisations namely churches, civil society and trade unions. 
Another feature of the Swazi customary law is that it has attracted very scant intellectual attention until recently when it occupied centre stage in Constitutional discourse. Writing in 1985, Bennett argues that 'Swaziland is in the unhappy position of having no comprehensive texts concerned with customary law and very little in the way of precedence'. 8 The only classic works which have been relied upon heavily in Eswatini for ascertainment of Swazi customary law are Marwick, The Swazi (1940) and Kuper, An African Aristocracy (1947) and Kuper, The Swazi (1963). ${ }^{9}$

Another striking feature of Swazi law is that, unlike other African systems that have suffered the flurry of manipulations by statute, Constitution and other forms, Swazi law has received protection and reinforcement from statutory law and the Constitution. Statutory law, and the Constitution in recent times, have been used to preserve certain aspects of socio-political life for customary law. Institutions such as offices of iNgwenyama, Ndlovukati, chieftaincy, the National Council, regency and many more remain protected terrains of Swazi law and custom. 10

Ever since Swaziland (now Eswatini) got independence, ${ }^{11}$ the Constitutions have always embodied provisions on succession to the office of monarch. However, these provisions have been consistent in their deference to "swazi law and custom" as the basis for succession to the office of monarch. The Constitutional provisions on succession are not elaborate beyond cagily providing that succession shall be based on "swazi law and custom". This Constitutional formulation evokes two Constitutional problems. The first one is that the Constitution abdicates its supremacy to another branch of the law which, however important it may be, is an ordinary law. In that way, customary law continues to occupy undue socio-legal pre-eminence in the Swazi society which renders misuse inevitable. ${ }^{12}$ Another Constitutional conundrum brought about by this formulation is that Swazi customary rules of succession to kingship are largely shrouded in uncertainty and secrecy.

The purpose of this paper is to critique this Constitutional formulation. In its critique, the paper analyses both the Constitution and Swazi customary law with a view to sustain an argument that the Constitution can regain its supremacy by codifying the customary rules of succession. When those roles have been codified in the Constitution, they can easily

8 Bennett The Application of Customary Law in Southern Africa (1985) 36.

$9 \quad$ Kuper The Swazi: A South African Kingdom (1963) 54.

10 Generally, see Chapter II of the Swaziland Constitution of 2005.

11 Swaziland (now Eswatini) got independence from Britain on 6 September 1968.

12 Hlatshwayo The ideology of traditionalism and its implications for principles of Constitutionalism: the case of Swaziland (LLM Thesis, York University 1992); Potholm Swaziland: the dynamics of political modernization (Berkeley, Los (1972); Booth Swaziland: tradition and change in a Southern African Kingdom (1983). 
be synchronised with other devices of Constitutionalism such as human rights, supremacy of the Constitution and many others. ${ }^{13}$

The paper is largely divided into three sections. The first section presents an analysis of the swazi Constitutional rules of succession since independence. The second part critically presents the customary rules and institutions governing succession to kingship. The third part presents a liberal critique of the broader notion of patriarchy in succession to leadership under custom, and kingship in particular.

Methodically, the paper pieces together the decided cases, the historic reports of the formative years and the classic works on the history of the country. The paper also makes intermittent comparisons with the Kingdom of Lesotho - which the Kingdom of Eswatini shares a lot of historical and Constitutional conventions with - and the Republic of South Africa which is a trailblazer on the development of customary law in a modern Constitutional state. ${ }^{14}$

\section{Rules of succession under swazi post- independence Constitutional designs}

The post-independence Constitutional trends in Eswatini regarding accession to the office of king depict constant pattern; customary law has been, and still remains, the central determinant of succession. The trend of Constitutional deference to customary law on matters of succession to office of king started to take ground with the 1967 pre-independence Constitution. ${ }^{95}$ The Constitution provided that:

When an announcement is made to the Swazi nation in accordance with Swazi law and custom that the office of king is vacant by reason of the death of the holder thereof or any other cause, such person as, in accordance with

Swazi law and custom, is declared to be King shall become King. ${ }^{16}$

13 See Fombad "The Swaziland Constitution of 2005: can absolutism be reconciled with modern constitutionalism?" 2007 South African Journal on Human Rights 93. At 93 the author observes that, "despite its veneer of Constitutionalism and Constitutional legitimacy, the new Constitution does little to protect the Swazis against the excesses of the authoritarian tendencies and practices of their King and his officials. The Constitution fails to reconcile the monarchy with modern Constitutionalism because it neither provides the barest minimum conditions for a functioning Constitutional monarchy nor for a democratic order".

14 Himonga and Bosch "The application of African customary law under the Constitution of South Africa: problems solved or just beginning" 2000 South African Law Journal 306; Albertyn 'The stubborn persistence of patriarchy'? Gender equality and cultural diversity in South Africa" 2009 Constitutional Court Review 165; Rauterbach "South African common and customary law on intestate succession: a question of harmonisation, integration or abolition" 2008 Journal of Comparative Law 119.

15 See the Swaziland Constitution Order 1967 (SI 1967 No 241).

16 S 18. 
The same principle applied in the case of Ndlovukazi (queen mother), ${ }^{17}$ and the Regent. ${ }^{18}$ This principle of recognising the office of Ngwenyama as king and head of state, whose succession was to be governed by Swazi law and custom seems to have occupied the centre-stage in the run-up to independence. It was mooted in the Constitutional proposal of $1966 .{ }^{19}$

The independence Constitution of 1968 did not introduce any change to the enduring principle of deference to "Swazi law and custom" on matters of succession to the office of king. ${ }^{20}$ The principle appears to be so enduring in the Swazi Constitutional design of post-independence that it appears to have even survived the country's 1973 Constitutional crisis. Instead, it could be safely argued that the 1973 Constitutional crisis marked the victory of "Swazi laws and custom" over the rival scheme brought about by the Westminster Constitutional design. In fact, King Sobhuza II himself said in the 1973 Proclamation:

The Constitution has permitted the importation into our country of highly undesirable political practices alien to and incompatible with the way of life in our society and designed to disrupt and destroy our own peaceful and constructive and essentially democratic methods of political activity ...21

The repeal of the 1968 Constitution in 1973 ushered in a new Constitutional dispensation in which customary law grew beyond the mere role of determining succession to the office of King but occupied the entire political and Constitutional space of the kingdom thereby fortifying the power base of the monarch. ${ }^{22}$ After almost three decades of the rule by Decree, ${ }^{23}$ the new Constitutional dispensation was ushered in

17 S 19, which provides,

"(1) The person who is Ndlovikazi (Queen Mother) immediately before the making of the Swaziland Constitution Order 1967 is hereby recognized as the Ndlovukazi.

(2) When the Office of Ndlovukazi becomes vacant in accordance with Swazi law and custom, a person shall, in accordance with Swazi law and custom, be designated as the holder". It is important to note that both for Ngwenyama and Ndlovukazi the Constitution delegated provides that succession shall be regulated by "Swazi law and custom". It did not have any detailed guideline in S 20 . the subject of succession to these offices.

19 See the "Swaziland Constitutional Proposals" Cmnd. 3119 of 1966, London.

20 Section 29 of the Swaziland Constitution of 1968 provides, "when announcement is made to the Swazi nation in accordance with Swazi law and custom that the office of King is vacant by reason of the death if the holder or any other cause such person as in accordance with Swazi law and custom is declared to be king shall become King".

21 Proclamation by His Majesty King Sobhuza II (No 578) of 1978.

22 Wanda "The shaping of the modern Constitution of Swaziland: A review of some social and historical factors" 1991 Lesotho Law Journal 177.

23 For the analysis of the adoption of the new Constitution, see Langwenya "Recent legal developments - Swaziland" 2005 University of Botswana Law Journal 167. 
by the controversial 2005 Constitution. ${ }^{24}$ Its clause on succession to the throne provides that: ${ }^{25}$

(1) Succession to the office of King and ingwenyama is hereditary and governed by this Constitution and Swazi law and custom.

(2) Where the office of king and iNgwenyama becomes vacant, the successor to the throne shall be determined and declared in accordance with Swazi law and custom.

The slight difference in the newly introduced principle is that succession is no longer exclusively governed by "Swazi law and custom". The new formulation provides that succession "shall be governed by this Constitution and the Swazi law and custom". Ironically, nowhere does the Constitution itself articulate rules or guidelines governing succession, which suggests that customary law still remains the arbiter on matters of succession to the throne. The net effect is therefore that rules of succession to the throne are based on "Swazi law and custom" as discussed above.

\section{Swazi customary rules and institutions governing succession to kingship}

\section{Customary rules of succession}

Law of succession is another aspect on which Swazi customary is different from that of most African countries, in that whilst it is still patrilineal in nature, it does not follow the rule of primogeniture strictu sensu - a right of inheritance does not necessarily belong to the eldest son of the king. ${ }^{26}$ Unlike in other African countries, where it is a matter of common course that the first son of the first wife succeeds, the successor in Eswatini is selected only after the death of the father. "The heir to the throne is not usually or widely known during the life of the Ngwenyama". 27

This is in keeping with the Swazi saying that 'no King can appoint his successor'. According to custom, inkosi yinkhosi ngenina (a king is king through his mother). The only settled principle is that "the King inherits his position in the male line. He is chosen from among the sons of his

\footnotetext{
24 The Constitution of Swaziland Act No 001 of 2005. For the analysis of the Constitution was adopted and the fault-lines in the process see Maseko "The drafting of the Constitution of Swaziland, 2005" 2008 African Human Rights Law Journal 312.

$25 \mathrm{~S} 5$ of the Constitution of Swaziland.

26 Voster and De Beer "Succession to Bukhosi among the Swazi of Mpumalanga Province” 2000 South Africa Journal of Ethnology 143 at 145.

27 Potholm "Swaziland under Sobhuza II" in Daniel et al (ed), Politics and Society in Swaziland (1975) 233.
} 
father by virtue of his mother's rank in the harem". 28 Whilst it is commonly known that in countries like Lesotho that the heir owes his position to the rank of his mother, the Swazi system demonstrates distinction in that it does not automatically accept the first wife as the main wife. ${ }^{29}$ According to Swazi maxim, "a first wife does not dispute the homestead". 30 The main wife is so designated and ranked by the council guided by several factors. Voster and de Beer identity these factors as, "the origin of the wives of the former traditional leader, the manner in which they joined the ruling family and substitution, as well as physical and natural characteristics of the successor". 31

Perhaps it may be proper to explain these factors briefly, as they are critical in the ultimate choice of the heir.

First, it is a matter of customary practice that the King's first wife, although she still has important functions in the harem, cannot be the Great Wife. The king's first and second wives must come from the Matsebula and Motsa clans respectively. They have ritual importance as sisulamsiti esikhulu (first wife) and sisulamsiti esincane (second wife) respectively. ${ }^{32}$ Thereafter the King is at liberty to marry from the 'foreign' clans from whom the Great Wife will come. In the past, the Great Wife has been from the clans of Mkhatshwa, Khumalo, Simelane, and Hlophe. ${ }^{33}$

The rank of her family is very important. According to Marwick, "the main wife of a king may be selected by the royal family council from the family of a leading chief, and married with a ritual". 34 The manner in which the wife is married is also critical. The girls who are married through arranged marriages stand a high chance of being main wives. Arranged marriages refer to a marriage, which is the affair of the families of both the future man and the wife. Their views as future husband and wife are of less importance; in fact, they are often not even consulted. "If the initiative is taken by the man or his family, they 'beg' the girl from her group with special beast to 'open the mouth' and her position as Great Wife is almost definitely assured". 35 Furthermore, a girl who chooses a husband for herself (utiganela) stands very little chance of

28 Kuper 2 at 54. The author provides the theoretical basis for this posthumous selection in that 'Swazi laws of succession and inheritance "... demonstrate a conscious attempt to overcome the lines of fission that are likely to endanger the unity of the group concerned', 88. Ironically, my field work at Mbabane, Lobamba and Mazini demonstrates that succession disputes in Swaziland are rifer, arguably because of the uncertainty that characterises the rules that govern it".

29 Kuper 88

30 Kuper 91. This means that she is not expected to claim the position of the main wife.

31 Kuper 145

32 Marwick 255.

33 Marwick 255.

34 Marwick 254.

35 Marwick 93. 
being ranked high as the main wife. The factors of how one was married and the social rank of the parents of the wife are interrelated because "aristocrats ... seek men of equal rank for their daughters, in order that a girl may retain the high social status, and they ask for more marriage cattle than do commoners as a mark of rank and wealth". 36

Another determinant factor is the character of the wife. Although it is generally believed that the character and rank of the parent determine that of the daughter, the character of the daughter itself is still a character. According to Kuper:

... in certain cases 'good character' - defined primarily as kindness and generosity - may win for individuals who would otherwise remain insignificant the positions of main wife and heir. ${ }^{37}$

As it would immediately appear, character is one of the most subjective factors in the process of choosing the main wife. However, there is evidence to the effect that Queen Mother Labotsibeni Gwamile Mdluli, ${ }^{38}$ was chosen almost exclusively on the basis of her good personality because her father was not even the highly ranked chief, save to say that she was allegedly the child of the levirate.

Most of the informants consulted in this study, particularly those who were related to the royal family largely confirmed these factors although there is still much secrecy when it comes to the finer details. ${ }^{39}$ The widely held view among the ordinary Swazi is that the actual knowledge of these factors is the exclusive preserve, sometimes the machinations, of the royal family.

The non-exhaustive nature of these factors only attests to one thing that the ruling family council, like the lelapa (family) in the case of Sesotho custom, has significant discretion in choosing the successor. Matsebula, one of the revered authorities on Swazi history and custom, attests to the fact that, according to Swazi law and custom, succession does not go according to primogeniture. However, he seems to contest the argument that Swazi custom on succession to bukhosi (kingship) is not definitive. He contends, "the Swazi King inherits his position in the male line, and is chosen from among the younger sons of the previous King. Because of our polygamous system, those who do not understand our custom feel that our method of choosing a king is complicated". 40

\footnotetext{
36 Marwick 93.

37 Kuper 103.

38 Queen Mother Gwamile was the mother of King Bhunu and grandmother of King Sobhuza II. She ruled Swaziland as the regent in the period 18991921. For a detailed discussion of her special character, see Ginindza "Labotsibeni/Gwamile Mdluli: The power behind the Swazi throne 18751925” 1997 Annals of the New York Academy of Sciences 135.

39 The informants on swazi customary rules on succession largely prefer anonymity because the rules are generally not up for general public engagement.

40 Matsebula A History of Swaziland (1976) 8.
} 
According to Matsubula, the choice of the successor is generally deferred to the time when the incumbent is dead. In other words, during the lifetime of the father, ordinarily no one knows who the heir will be not even the father himself. It is only after the demise of the father that the royal family council meets and decides who among the queens will be the queen mother. Matsebula confirms what Voster and De Beer say, namely that there are certain factors considered when choosing the queen mother. One of the principal criteria is "the mode of marriage of different queens". 41

The main theory of the Swazi law of succession is peace and unity of the family. It is based on the presumption that if the heir to the throne can be known before the death of the incumbent father there will be strife for the power and wealth that come with the office. Kuper aptly captures the theory as thus:

... strife for succession often intensifies factions within each hostile faction, it weakens the larger unit. Swazi consider that when the heir is not known, the kingship group has greater solidarity: co-wives and their sons are likely to remain on terms of equality and friendship, and the position of the father is more secure, since there is less likelihood of ... a possible attempt to hasten his death. ${ }^{42}$

While this presumption holds at times, it has not always proved accurate as the uncertainty about the heir gives rise to competing ambitions and tacit strife.

\section{Traditional institutions and procedures for succession in Eswatini}

The key institution that customarily deals with succession is bantfanenkosi (princes of the blood). The bantfanenkosi comprises the male members of the royal family only. When it meets for the purposes of succession, the sons of the deceased King from whom selection is going to be made, do not participate. The next brother of the late King normally chairs the council. ${ }^{43}$ In terms of procedure, when the king passes away the bantfanenkosi together with the indvuna (chairperson) of the Indlovukati's village and with the tinsila (blood brothers) of the late King, meet to decide succession. ${ }^{44}$ Although the incumbent Indlovukati does not physically sit with the council for the choice of the heir, she is very much involved in the process as she remains referable on points of material significance.

When the choice has been made by the bantfanenkosi, the national libandla (the general assembly of all men of the nation) and Indlovukati are informed of the choice. The minor heir will be called umtwana (child)

41 Matsebula 8

42 Kuper 89.

43 Marwick 257.

44 Marwick 257. 
until his time of installation as the Ingwenyama. His mother, because of whose status the child was chosen, will then be the Indlovukati.

Although public presentation of the newly appointed heir appears to be a critical step in the process of appointment, there is no evidence that national libandla can object or otherwise express any meaningful dissatisfaction to the choice. The choice is predominantly the preserve of bantfanenkosi. However, according to custom, the choice of the heir is completed by public presentation to the libandla.

\section{A critique of customary rules}

The question of how the currently ruling dynasty came to power is a matter of considerable controversy. However, the tribe can be traced back to King Ngwane III, which has survived and established hierarchical and successive institutions, which, according to Motsebula, "have survived to the present day". "Although Matsebula would want us to believe that Swazi custom on succession is 'fairly simple', the deeper one sinks into its research the more complications surface. There are certain general rules like the ones outlined above, which are straightforward and which need no further elaboration, but there are certain rules plagued by deliberate vagueness. The polygamous nature of marriage in Eswatini, also further compounds the problem. The rules that guide the royal council (bantfanenkosi) during the choice of the queen mother are not so obvious, thereby leaving much room for discretion or, at times, whims. For instance, while it is one of the criteria that the queen mother must have only one son, there is some evidence that for Labotsibeni Mdludi, mother of King Bhunu and grandmother of Sobhuza II had three sons, but her character was so strong that the royal council agreed that she must be Ndlovukazi. ${ }^{46}$ Whilst in other countries like Lesotho the major uncertainty has in the past been the choice of a regent, ${ }^{47}$ in Eswatini it would seem that the problem is really choosing the mother of the King. If the King is still a minor, the new Ndlovukazi acts as regent, helped by the King's brother. The royal council must also appoint the brother. ${ }^{48}$

This open-endedness of the rules of succession has never gone without much of succession disputes. Since the early days of the Swazi tribe, succession disputes have been rife. In fact, every time there is a new King to be appointed, there are succession disputes. According to Gillis:

... the first disruptions were domestic family dissention among the Dlamini over Sobhuza's successor. Other sons, offspring from the late King's polygamous marriages, had valid claims to the kingship and were not slow to press them. ${ }^{49}$

45 Marwick 8.

46 Marwick 8 ,

47 See Bereng Griffith v. Mants'ebo Seeiso 1926 HCTLR 53.

48 Matsebula 8.

49 Gillis The Kingdom of Swaziland: Studies in Political History (1999) 20. 
The succession dispute did not only follow the death of Sobhuza; even that of his successor Mswati was fraught with controversy. Gillis notes that the King's demise was followed by a decline in Swazi influence and power. Part of the reason was that custom left open the door to succession and as had happened before, too many aspirants passed through so "when the question of succession arose twenty of his sons had supportable claims to the kingship". 50

It would seem that the Constitution of Swaziland will continue to cause trouble regarding succession as long as the matter is left exclusively to custom. Custom is dynamic, and develops from time to time and as a result, the rules that regulated succession during the reign of Sobhuza I may have been changed by practice. The challenge with this modus operandi is that, despite the significance of monarchical succession in the Constitutional design, rules remain largely unwritten at the behest of the bantfanenkosi.

\section{Patriarchy, primogeniture rule and the liberal Constitutional theory}

Clearly, the most discernible trend since colonialism has been the steady decline of the power of hereditary monarchy yielding to the emergence of electoral democracy. Even the Constitutional designs have been attuned to this trend. The outcome of the investigation of the customary modes of accession give mainly three results which will, at first sight, appear to sit rather uncomfortably with the demands of the post-colonial Constitutional designs - which, by the way, are largely informed by the conceptions of colonial state craft. Firstly, determination of hereditary succession is the preserve of a certain exclusive dynastic group-styled bantfanenkosi, or the College of Chiefs, whatever the case may be - not the entire society within the polity. Secondly, aspiration to accede to the office of King is limited to those borne within a certain family - therefore the exclusive privilege of the few individual offspring of that lineage. Thirdly, the rules of succession are largely patriarchal. These three variables in themselves put hereditary succession in a position of perpetual tension with the Constitutional design, whose lodestar is Constitutional democracy. It is therefore befitting to examine how

50 Gillis 25. The succession disputes still rages within the Swazi royal family even to this day. The crux of it is captured more accurately by Vilane and Daniel. According to them, one of the critical elements that sharpened and complicated the conflict situation in Swaziland is the "division within the royal family dating back to the controversial selection in 1899 of Sobhuza as successor to King Bhumu (Mahlokohla). Today this schism centres upon the personage of Prince Mfanasibili who is held in awe by many within the aristocracy as he is a son of Prince Makhosikhosi who, according to Swazi oral tradition (or one interpretation of it), was the true heir to Mahlokohla throne, and not Sobhuza". See Daniel and Vilane "Swaziland political crisis: regional dilemma” 1986 Review of African Political Economy 54 at 58. 
heredity contends with the colonial imprints, which have come to be the whirlwinds of the contemporary Constitutional design.

As demonstrated in the preceding sections, accession to high office in Eswatini is hereditary. As Schapera captures it:

Chieftainship is hereditary ... a chief succeeds automatically to his office by right of birth ... a chief is a chief because he is born to it ... 51

Accession is not subject to an electoral process. This underlying feature of a monarch, at least at first instance, appears "to remove from this institution any semblance of democracy". 52 This tension is further heightened by the promise given since independence that the kingdom will be "democratic". 53 The assault on heredity has been rife in the postcolonial Constitutional debate not only of the Kingdom of Eswatini, but also of many other African states. Scholars, even African scholars, contend that the fall of colonialism and ascendancy of electoral democracy in the middle of the $20^{\text {th }}$ century in Africa marked the consequent collapse of any form of government whose authority to rule is not subject to popular participation of the people. Rugege, for instance, contends, "the right of hereditary rule is fundamentally undemocratic". 54 Some scholars like Makoa have been very radical and unsympathetic to the institution of chieftainship to the extent that they argue for its dispensability. Makoa, who appears to juxtapose the institution with militarism, argues that countries must reappraise their systems of rule and structure of government "by applying an economic and political criterion. Thus, assessed in these terms chieftainship and the military are first of all the institutions that are clearly dispensable". 55

The careful consideration of the stream of authorities that degrade monarchism because of heredity demonstrates that these are scholars whose conception of democracy is not Western but they are a rubric of democrats that Fayemi calls minimalists - scholars whose viewpoint on democracy is election. ${ }^{56}$ The leading minimalist democrat, Schumpeter, contends that democracy is a "method by which decision making is

51 Schapera "Political institution" in Schapera (ed), The Bantu Speaking Tribes of South Africa: An Ethnographical Survey (1937) at 173-175.

52 See Mokgoro "Traditional authority and democracy in the Interim South African Constitution" 1996 Review of Constitutional Studies 60 at 62.

53 S 1(1) of 2005 Constitution provides that 'Swaziland is a unitary, sovereign, democratic Kingdom' Another precept of liberal Constitutionalism Constitutional supremacy - is embodied under section 2(1) of the same Constitution. It provides that '[t]his Constitution is the supreme law of Swaziland and if any other law is inconsistent with this Constitution that other law shall, to the extent of the inconsistency, be void'.

54 Rugege "The future of traditional hereditary chieftaincy in a democratic Southern Africa: The case of Lesotho and South Africa" in Santho \& Sejanamane (eds), Southern Africa after Apartheid (1991) 48 at 156.

55 See Makoa "The military Kingdom: A case for restructuring the system of government in Lesotho in the 1990" in Santho \& Sejanamane 182.

56 Fayemi "Towards an African theory of democracy" 2009 Thought and Practice 101. 
transferred to individuals who have gained power in a competitive struggle for the votes of the citizens". 57 For minimalists, election as opposed to heredity is the central theme of democracy. However, contemporary debate on the discourse of democracy while it does not necessarily downgrade the essence of elections in a democracy is inclined to suggest that democracy is more than election. ${ }^{58}$ Diamond, one of the leading contemporaries in this latter trajectory, opines that further to elections, liberal democracy - which is arguably the one bequeathed to the Kingdoms of Eswatini at independence - demands institutions accountable to somebody else other than themselves. ${ }^{59}$ Although it is not immediately clear whether Diamond would accept liberal democracy - executive authority with Constitutionally constrained powers - without elections, what is clear though is the fact that liberal democracy is not so much obsessed with elections but with Constitutionalism. In fact, Huntington has dared to contend quite convincingly that:

Elections in non-Western societies may lead to the victory of political leaders or groups that seriously threaten the maintenance of democracy. Elected chief executives in Latin American countries and in former soviet republics have often acted arbitrarily and undemocratic ways ... ${ }^{60}$

Thus, the growing disenchantment with elections and the growing mass of literature re-affirming African governance systems, ${ }^{61}$ have obviously weakened the indictment of electoral democrats on hereditary succession. Thus, the salient question for hereditary rulers is no longer about the manner in which they get to power but, rather, whether their executive power is limited and accountable to other institutions when they are in power.

One of the daunting challenges in the modern-day hereditary monarchy in general, and in the case of Eswatini in particular, is that

57 Schumpeter Capitalism, Socialism and Democracy (1942) 269.

58 See Diamond "Is the third wave over?" 1996 Journal of Democracy 20 at 21.

59 Diamond 23.

60 Huntington "After twenty years: the future of the third wave" 1997 Journal of Democracy 3. This article was his own appraisal of the arguments raised by himself about six years earlier in The Third Wave of Democratization in the Twentieth Century (1991, University of Oklahoma Press).

61 See Fayemi 109. The author argues that: "[I]n a bid to justify the imposition of civilized government on their colonial territories, European imperialists characterized African pre-colonial political structures as autocratic and oppressive. Nonetheless, that conception was grossly inaccurate for many traditional African societies ... An investigation into their socio-cultural history will reveal the democratic structure of their political-cultural heritage, evident in their process of choosing leadership ...”. The equally impassioned attack on the imposition of Western democracy is made by Ake The Feasibility of Democracy in Africa (2000) 34 as thus: "Africa, it has been claimed, has its own unique history and traditions and the introduction of democracy, an alien concept, would violate the integrity of African culture. This argument premised on the misconception that democracy is solely a Western creation, stems from confusion between the principles of democracy and their institutional manifestation". 
accession to high office is preserved for the male line. This is the aspect of customary norms and values, which even the Westminster Constitutional model adopted in Swaziland at independence, never dared to challenge. As has been demonstrated earlier, one of the critical challenges of the post-independence Constitutional designs in Eswatini is that as it relates to monarch, is that the Constitution is not self-contained - it demonstrates substantial deference to customary law and the general rubric of customs. Thus, male domination is one of the most pervasive features of custom. Yet, one of the streams that nourish the contemporary Constitutional theory is equality. The Constitution of Swaziland (latterly Eswatini) embodies this value. ${ }^{62}$ Equality, freedom (liberty) and justice are the fundamental pillars of Constitutional theory based on liberal democracy. ${ }^{63}$ In addition, in an effort to uphold these values, the Bill of Rights in the Constitution of Swaziland also embodies, in a broader way, these values. ${ }^{64}$

This conflict-ridden relationship between contemporary values of Constitutionalism based on liberal political philosophy, ${ }^{65}$ and custom has become a subject of intensive judicial, ${ }^{66}$ as well as scholarly, ${ }^{67}$ engagement in other countries in the sub-region like in South Africa. ${ }^{68}$ The post-apartheid South African Constitutional dispensation had to grapple with the role of chieftaincy within the new Constitution based on liberal values - but much more specifically with the rule of primogeniture. As Bank and Southall point out:

62 S 20 of the 2005 Constitution provides that: (1) All persons are equal before and under the law in all spheres of political, economic, social and cultural life and in every other respect and shall enjoy equal protection of the law. (2) For the avoidance of any doubt, a person shall not be discriminated against on the grounds of gender, race, colour, ethnic origin, tribe, birth, creed or religion, or social or economic standing, political opinion, age or disability. (3) For the purposes of this section, "discriminate" means to give different treatment to different persons attributable only or mainly to their respective descriptions by gender, race, colour, ethnic origin, birth, tribe, creed or religion, or social or economic standing, political opinion, age or disability.

63 MC Vile Constitutionalism and Separation of Powers (1998, 2nd ed, Liberty Fund) at 1.

64 See Chapter III of the 2005 Constitution of Swaziland styled "Protection and Promotion of Fundamental Rights and Freedoms".

65 See Loughlin "Constitutional theory: a $25^{\text {th }}$ anniversary essay" 2005 Oxford Journal of Legal Studies 183.

66 Mthembu v Letsela and Another 19982 SA 675 (T), which was later upheld in Mthembu $v$ Letsela and Another 20003 SA 867 (SCA); Zondi v President of the RSA 20002 SA 49 (N); Bhe v Magistrate, Khayelitsha 20051 SA 580 (CC).

67 Kerr "Customary law, fundamental rights, and the Constitution" 1994 South African Law Journal 720; also Mireku "Judicial balancing of parallel values: male primogeniture, gender, equality and chieftaincy succession in South Africa" http://www.enelsyn.gr/papers (accessed 2018-08-24) and Kerr "The Constitution, the bill of rights and the law of succession" 2006 Speculum Juris 1 .

68 Omotola "Primogeniture and illegitimacy in African customary law: the battle for survival of culture" 2003 Speculum Juris 181; Juma "From 'repugnancy' to 'bill of rights': African customary law and human rights in Lesotho and South Africa" 2007 Speculum Juris 88. 
... the Constitution is based primarily upon notions of liberal and Constitutional democracy. Nonetheless, it simultaneously provides for the recognition of existent legally constituted traditional authorities ... ${ }^{69}$

The Constitutionality of the primogeniture rule, although it was not dealing with succession to monarchy, came into issue in the Constitutional Court through the case of Bhe $v$ Magistrate Khayelisha. ${ }^{70}$ Langa DJC clearly impugned the rule as:

The principle of primogeniture ... violates the right of women to human dignity as guaranteed in section 10 of the Constitution as, in one sense, it implies that women are not fit or competent to own and administer property ... Their dignity is further affronted. ${ }^{71}$

While the court was more cautious in the Bhe case not to extend its ruling to cover the cases of succession to traditional chieftaincy, it was not long before a direct case of succession to chieftaincy was brought before the court. The court was directly confronted by the Constitutionality of the primogeniture rule with regard to chieftaincy in the landmark case of Shilubana $v$ Nwamitwa. ${ }^{72}$ The facts of this case are interesting and of peculiar relevance to Eswatini. The dispute arose in the Valoyi traditional community in the province of Limpopo in South Africa following the death of Hosi (chief) Richard Nwamitwa in 2001. The appellant, Ms Shilubana, was the daughter of former Hosi Fofosa Nwamitwa who had died without a male heir around 1968. Customary law of succession at the time, like that of Eswatini, went according to male line, thereby disallowing the daughter, Ms Shilubana, to succeed despite being the eldest child. ${ }^{73}$ Instead, Hosi Fofosa's brother succeeded. In 1996 and 1997, the Valoyi traditional authorities resolved that in view of the new Constitutional dispensation, which cherished gender equality, Ms Shilubana would succeed Hosi Richard. Hosi Rechard's eldest son, Mr Nwamitwa contested the resolution. Both the High Court ${ }^{74}$ and the Supreme Court of Appeal upheld his contest. ${ }^{75}$

When the appeal was launched in the Constitutional Court, the main issue was whether the decision by the traditional authorities to appoint Ms Shilubane as the heir was Constitutional. The court held that:

The Valoyi authorities intended to bring an important aspect of their customs and traditions into line with the values and rights of the Constitution. Several provisions of the Constitution require the application of the common law and customary law, as well as the practice of culture or religion, to comply with the Constitution. Sections 1 (c) and 2 establish the supremacy of the Constitution over all law. Section 30 recognises the right to participate in the

69 Bank and Southall "Traditional Leaders in South Africa's New Democracy" 1996 The Journal of Legal Pluralism 407.

70 Bhe $v$ Magistrate, Khayelisha supra.

71 Bhe v Magistrate, Khayelisha para 92.

7220089 BCLR 914 (CC).

73 Shilubana $v$ Nwamitwa para 51.

74 Nwamitwa $v$ Phillia 20053 SA 536 (T).

75 Shilubana $v$ Nwamitwa 20072 SA 432 (SCA) 
cultural life of one's choice, but only in a manner consistent with the Bill of Rights. ${ }^{76}$

The purport of this ruling is therefore that the primogeniture rule in South Africa is as unconstitutional with regard to private inheritance, ${ }^{77}$ as it is with succession to chieftainship. As Bank and Southhall perhaps poignantly observe, the Constitutional dispensation in the Republic of South Africa would still, at some point in its development, have to deal with that paradox.

They argue that the new Constitutional order is based on liberal values but at the same time seeks to preserve the traditional values. ${ }^{78}$ This observation may be equally true of the contemporary Constitutional dispensation in Eswatini. The 2005 Constitution of Swaziland, for instance, cherishes the right to "equality before the law". 79 The Constitution of Swaziland is so outright on this principle to the point of being superfluous that it provides "for the avoidance of any doubt, a person shall not be discriminated on the grounds of gender". Lesotho is no exception. However, while Lesotho's Constitution still generally cherishes liberal values and equality in particular, it is still cautious in its preservation of patriarchy. It places "the application of customary" as the justifiable exception to the principle of equality. ${ }^{80}$ Be that as it may, it can still be observed that the principle of primogeniture, although it is so central and the bulwark of customary law of succession, will remain in constant tension with the contemporary Constitutional theory.

Another comparative lesson is from the recent decision of the Court of Appeal of Lesotho on this tension is in the case of Senate Masupha $v$ Senior Resident Magistrate for the Subordinate Court of Berea. ${ }^{81}$ Although the case relates to the application of customary rules to the lower tier of chieftainship, - principal chieftainship - it attests to these continuing tensions between customary rules and virtues of liberal democracy in the Constitution. In casu the appellant was an unmarried woman whose father was, until his death the principal chief of Ha 'Mamathe, Thupa-

76 Shilubane $v$ Nwamitwa para 68. For the dedicated analysis of this dictum, see Mmusinyane "the role of traditional authorities in developing customary law in accordance with the Constitution: Shilubane and Others v Nwamitwa 2008 BCLR 914 (CC)" 2009 Potchefstroom Electronic Law Journal 136. See also Khunou "Traditional Independent Bantustans of South Africa: Some Milestones of Transformative Constitutionalism Beyond Apartheid" 2009 Potchefstroom Electronic Law Journal 81, who uses this decision to demonstrate that the new Constitutional dispensation in South Africa does not allow any form of discrimination. The author at 110 argues that: "[t]raditional leadership is recognized subject to the 1996 Constitution and is required to be compatible with the Constitution. This Constitutional provision requires the traditional leadership to change its own rules and practices not to be in conflict with the Bill of Rights".

77 See Bhe $v$ Magistrate supra.

78 Bank and Southall 408.

79 See s 20(2).

80 See s $18(4)$ (c).

81 C OF A (CIV) 29/2013 (yet unreported). 
Kubu and Jorotane in the Berea district. His widow, the appellant's mother, succeeded the father. Upon her death in December 2008, the office of principal chief fell vacant.

In February 2009, a family meeting was held pursuant to which Lepoqo David Masupha, the then minor son and only issue of a subsequent marriage entered into by the appellant's late father, was named as successor to the chieftainship, and a regent was appointed pending his majority. The decision of the family council was based on customary rule of primogeniture, which has since been codified under section $10,{ }^{82}$ of the Chieftainship Act. ${ }^{83}$ The appellant challenged the decision of the family council based on the principle of nodiscrimination, ${ }^{84}$ and equality, ${ }^{85}$ enshrined in the 1993 Constitution of Lesotho. Both the High Court and the Court of Appeal were unanimous in dismissing the challenge. The main reason as extolled by the Court of Appeal was that since the Constitution itself sanctions the limitation to the rights to equality and non-discrimination based on customary law, it cannot be argued that customary rule of primogeniture is unconstitutional. ${ }^{86}$ The court simply confirms that the tension of values of liberal Constitutionalism and customary law have permeated, in a major way, the post-colonial Constitutional designs in both kingdoms under study.

82 The section codifies the rule as thus, (2) When an office of Chief becomes vacant, the firstborn or only son of the first or only marriage of the Chief succeeds to that office, and so, in descending order, that person succeeds to the office who is the first-born or only son of the first or only marriage of a person who, but for his death or incapacity, would have succeeded to that office in accordance with the provisions of this subsection. (3) If when an office of Chief becomes vacant there is no person who succeeds under the preceding subsection, the first-born or only son of the marriage of the Chief that took place next in order of time succeeds to that office, and so, in descending order of the seniority of marriages according to the customary law, that person succeeds to the office who is the first-born or only son of the senior marriage of the Chief or of a person who, but for his death or incapacity, would have succeeded to that office in accordance with the provisions of this subsection. (4) If when an office of Chief becomes vacant there is no person who succeeds under the two preceding subsections, the only surviving wife of the Chief, or the surviving wife of the Chief whom he married earliest, succeeds to that office of Chief, and when that office thereafter again becomes vacant the eldest legitimate surviving brother of the male Chief who held the office last before the woman, succeeds to that office, or failing such an eldest brother, the eldest surviving uncle of that male Chief in legitimate ascent, and so in ascending order according to the customary law. The Court of Appeal confirmed in the same case that customary law of succession has been codified under the aforesaid section. At para 15 the Court decided that: "the Act, and s 10 in particular, make provision - as stated in s 18(4)(c) of the Constitution - for the application of the customary law of Lesotho with respect to (chieftainship succession) in the case of persons who, under that law, are subject to that law".

83 Act 22 of 1968 (as amended).

84 S 18.

85 S 19.

86 See para 18 and 19 
The South African Constitutional edifice is distinguishable from that of the Kingdom of Eswatini in that it has a more comprehensive scheme in dealing with customary law and the Constitution. Whilst diversity of cultures is respected in South Africa, ${ }^{87}$ section 39(2) of the Constitution specifically requires a court interpreting customary law to promote the spirit, purport and objects of the Constitution. This is the main distinction between the place occupied by customary law in the Constitution of South Africa and the place it occupies in the Kingdom of Eswatini. Under South African Constitutional jurisprudence as confirmed by courts of law, ${ }^{88}$ customary law derives its validity from the Constitution - not the other way round. In the Kingdom of Eswatini, the Constitution appears to relinquish its supremacy to customary law.

\section{Conclusion}

The purpose of this article has been to study the rules of succession governing accession to the office of king in Eswatini. The article showed that the Constitutions of this kingdom, since independence in 1968, have consistently embodied a clause on succession to the office of king. What is striking, though, with the Constitution, is its deference to customary law.

Two important aspects appear problematic about this design. Firstly, besides establishing the office of king, the Constitution can generally be regarded as wanting on the guidelines governing accession to that office. Secondly, by demonstrating such consistent deference to customary law, the Constitutional design of Eswatini appears to abdicate its supremacy to customary law. This downplaying of the Constitution in favour of customary law became rife in Eswatini since 1973. ${ }^{89}$

Furthermore, reliance on customary law for the rules of succession to such high office - although it assists in retaining the traditional and customary content of this office - has also proved problematic over the years. ${ }^{90}$ In Eswatini, almost as soon as a new King has to be installed the transition is riddled with succession disputes. This may primarily be because customary law is a dynamic system of law and in the process

87 See s 31 of the 1996 Constitution of South Africa.

88 It the case of Alex and another $v$ Richterveld Community 200312 BCLR 1301 (a) at para 51 the court held that "while in the past indigenous law was seen through the common law ... it must now be seen as an integral part of our law, like all law it depends for its ultimate force and validity on the Constitution. Its validity must now be determined by reference not to common law but to the Constitution".

89 See the cases of Lucky Nhlanhla Bhembe v The King Criminal Case 75/2002 (unreported); Gwebu \& Another v Rex (2002) AHRLR 229 (SwCA 2002).

90 The problem is not only unique to Eswatini. It is a common problem throughout Africa. See White "African customary law: the problem of concept and definition" 1965 Journal of African Law 86. 
marred by uncertainties and ultimately renders the system open to abuse. ${ }^{91}$ This is confirmed by the relative disagreement on the rules of customary law governing succession. This divergence of views on customary law even transcends the efforts intended at codifying the system such as the Lerotholi Code in Lesotho. Confirming the fluidity of customary law in 1943, Lansdowne, J, in the regency case pointed out that:

In a country like Basutoland where customary practices are in general inconstant, tending under the influence of Christianity, education and others forces, to the improvement of a primitive social system, to the elimination of feudal privileges, and to the evidence from the idea of the family unit towards a larger appreciation of the rights of the individual, it is found undesirable to endeavour to reduce custom to written law, for thereby that which is course of wholesome development would tend to become static. ${ }^{92}$

Thus, even codes such as Lerotholi Code in Lesotho cannot be regarded as safe records of customary law. ${ }^{93}$

Lastly, it appears that notwithstanding the legitimate nature of hereditary succession to the office of King, the patriarchal nature of customary law poses a unique challenge in the contemporary Constitutional theory. ${ }^{94}$ The rule of primogeniture, which prefers males to females, is experiencing considerable problems in co-existing with the contemporary ethos of equality and dignity. The South African jurisprudence has taken a bold step forward to impugn the rule. ${ }^{95}$ Arguably, since the South African context is not so much remote, as it retains both hereditary and elected rulers, it may be safely expected that the Kingdoms of Eswatini will follow its precedence, at least progressively.

It can therefore be recommended the Constitution clause on succession to office of King be amended to elaborate the rules of succession. It serves Constitutionalism best when the rules by which

91 For the methods of ascertaining customary law, see Palmer and Poulter The Legal System of Lesotho (1972) 101-105. See further Poulter "An essay on African customary law research techniques: some experiences from Lesotho" 1975 Journal of Southern African Studies 181. The author opines that: "students of African affairs who come fresh to the field of customary law research will immediately be struck by three notable facts. First, it is a domain frequented as much by anthropologists as by lawyers. Second, it is an area presently experiencing rapid growth in terms of fieldwork ... Third, despite this ... progress towards consensus regarding the most appropriate research techniques to employ seems to be emerging only rather slowly".

92 Bereng Griffith v Mantsebo Seeiso Griffith n49 at 58.

93 Juma "The Laws of Lerotholi: Role and status of codified rules of custom in the Kingdom of Lesotho" 2011 Pace International Law Review 92.

94 Tebbe "Inheritance and disinheritance: African customary law and Constitutional rights" 2008 The Journal of Religion 466.

95 Bhe v Magistrate, Khayelitsha supra; Shilubane v Nwatiwa supra. 
rulers accedes to office are clearly articulated and Constitutionalised. ${ }^{96}$ The Constitutionalisation of the customary rules will resolve a twopronged problem with the rules of succession currently - the problem of uncertainty of rules and their non-Constitutional nature.

96 The view accords with de Smith's formulation that: "Constitutionalism in its formal sense means the principle that the exercise of political power shall be bounded by rules, rules which determine the validity of legislative and executive action by prescribing the procedure according to which it must be performed or by delimiting its permissible content". See de Smith "Constitutionalism in the Commonwealth today" 1962 Malaya Law Review 205. 